Chymia. Annual Studies in the History of Chemistry. Vol. i i. Ed. Henry M. Leicester. Pp. 208. 4os. net. University of Pennsylvania Press and Oxford University Press. 1966-67.

The Society of Arcueil. A View of French Saience at the Time of Napoleon I. By Maurice Crosland. $P p . x x+514.19$ plates and map. 84s. net. London: Heinemann. 1967.

Pioneers of Canadian Science: Symposium presented to the Royal Society of Canada in I964. Ed. G. F. G. Stanley. Pp. xiii + 146.8 plates. 40s. net. Toronto University Press and Oxford University Press. 1966.

Elias Ashmole (i6i 7-i692). His Autobiographical and Historical Notes, his Correspondence, and other Contemporary Sourges Relating To his Life AND Work. Ed. C. H. Josten. Pp. $x x+2,065.25$ plates. EI7 18 s. net. 5 vols. Oxford: Clarendon Press. 1966.

Sir Arthur Eddington. By C. W. Kilmister. Pp. vi + 278. 21s. net. Oxford: Pergamon Press. 1966.

Newton demands the Muse. Newton's "Opticks" and the EighteenthCentury Poets. By Marjorie Hope Nicholson. Pp. xi +178 . 22s. 6d. net. Princeton University Press and Oxford University Press. 1966 (paperback).

\title{
OBITUARY
}

\section{EVA G. R. TAYLOR}

We regret to record the death of Professor Eva G. R. Taylor on 5 July I966 at the age of 86. In 1930 she was appointed Professor of Geography in the University of London and in 1944 became Professor Emeritus. She was a Fellow of Birkbeck College, London, and Victoria Medallist of the Royal Geographical Society.

In the field of history of science she is probably best known for her definitive work, The Mathematical Practitioners of Tudor and Stuart England (1954). Her most recent book, The Mathematical Practitioners of Hanoverian England (1966) is reviewed in the current issue of this journal. Professor Taylor was an Honorary Member of the British Society for the History of Science.

\section{XIIth INTERNATIONAL CONGRESS OF THE HISTORY OF SCIENGE}

The XIIth International Congress of the History of Science will be held in Paris from 25 to 3 I August 1968.

Further details may be obtained from Mlle S. Delorme, I2 Rue Colbert, Paris 2. 